Volume 5 Number 2, July-December 2021: pg. 93-106.

Fakultas Hukum, Universitas Lampung,

Bandar Lampung, Lampung, Indonesia.

E-ISSN: 2598-3105 P-ISSN: 2723-2581

http://jurnal.fh.unila.ac.id/index.php/cepalo

\title{
ISLAMIC BANK SUSTAINABILITY IN INDONESIA: VALUE AND FINANCIAL PERFORMANCES BASED ON SOCIAL RESPONSIBILITY AND GREEN FINANCE
}

\author{
Helma Malini \\ Faculty of Economics and Business, Universitas Tanjungpura, Indonesia, \\ E-mail: helma.malini@untan.ac.id
}

Submitted: June 11, 2021; Reviewed: July 14, 2021; Accepted: July 16, 2021

DOI: 10.25041/cepalo.v5no2.2360

\begin{abstract}
This paper investigates the sustainability perspective of Islamic banks' financial decisions, performance, and corporate value where Corporate Social Responsibility (CSR) and green finance are moderation variables. The analysis method used multivariate statistical methods, structural equation modelling with the WarpPLS software program and testing panel data regression models using the E-Views software program. The datasets used involves 34 Islamic banks in Indonesia. This study found a significant relationship between CSR and green finance implementation to financial decisions, financial performance, and corporate value of Islamic banks in Indonesia. However, the relationship is heterogeneous or dissimilar across different quantiles. This means that CSR and green finance implementation only achieve short-term profit, not long-term sustainability. The study also reveals that corporate social responsibility contributes the most to Islamic banks' investment decisions and market value. Thus, policies focusing on integrated CSR in Islamic banking are required to improve sustainability opportunities.
\end{abstract}

Keywords: Islamic Banking, Firm Value, Financial Decision, Financial Performances, Corporate Social Responsibility, Green Perspective.

\section{A. Introduction}

Islamic Banking in Indonesia has shown significant development. However, Islamic bank development has lagged of conventional banks. ${ }^{1}$ Based on that reason, an Islamic bank needs to exist as a secure alternative investment. Thus, focusing on the three pillars of society, environment, and profit, known as the sustainability concept, are essential for Islamic banking. Sustainability is an emerging concept that was recently introduced in Islamic banking. However, evaluation of sustainability theory and practice in Islamic Banks has not been conducted. ${ }^{2}$ Sustainability was a social phenomenon that began with a strict

\footnotetext{
${ }^{1}$ Standard and Poor's Rating Services, "Standard and Poor Economic Finance Outlook 2019” (New York, 2019).

2 S. Aliyu et al., "Islamic Banking Sustainability: A Review of Literature and Directions for Future Research," Emerging Markets Finance and Trade 53, no. 2 (2017): 440-70, https://doi.org/10.1080/1540496X.2016.1262761.
} 
environmental interpretation at a UN conference in the 1970s and 1980s, then slowly known as Corporate Social Responsibility (CSR). ${ }^{3}$ Corporate social responsibility (CSR) is a corporate responsibility towards stakeholders that integrates concern for society and the environment in business operations. Corporate responsibility awareness has become a global concern. Apart from the pros and cons of CSR obligations, companies could refuse but still demonstrate their business ethics by obeying regulations. ${ }^{4}$

The rapid growth of Islamic banks in Indonesia was not followed by proper socialisation. Related institutions focused on the certification rather than awareness and understanding based on the Maqasid Al-Shariah principle. Maqasid Al-Shariah is an Islamic finance principle based on good corporate governance, fairness, transparency and accountability. ${ }^{5}$ Maqasid Al-Shariah is the heart of ushul fiqh science. Therefore, Maqasid AlShariah is critical in formulating Islamic banks' process and implementation. This concept complements the cosmetic industry's halal certification since haleness comes from the product and the process, including the ethics code. ${ }^{6}$ As a result, Muslims will look for acceptable products for consumption. Allah SWT says in Al-Baqarah verse 168, "O mankind, eat what is lawful and clean (thayyiban) on earth". Based on the verse, the call is addressed to all mankind, not just Muslims. This proves that halal and thayyiban are universal. Halal is anything that is religiously allowed.

The term thayyiban means good. However, the notion of thayyiban develops with the times. Thayyiban means beneficial and not harmful to the body and mind. For example, halal food containing balanced nutrition and damage could be thayyib. However, halal foods with harmful side effects, such as high sugar levels for diabetes, could not be classified as thayyib. Along with the times, thayyiban could be interpreted with feasibility, cleanliness and functional effects for humans. ${ }^{7}$

\footnotetext{
${ }^{3}$ Aloy Soppe, "Sustainable Finance as a Connection between Corporate Social Responsibility and Socially Responsible Investing," Indian School of Business WP Indian Management Research Journal 1, no. 3 (2009): 13-23, https://papers.ssrn.com/sol3/papers.cfm?abstract_id=1336182.

${ }^{4}$ Roger C. Y. Chen and Chen-Hsun Lee, "The Influence of CSR on Firm Value: An Application of Panel Smooth Transition Regression on Taiwan.," Applied Economics 49, no. 34 (2017): 3422-34, https://doi.org/10.1080/00036846.2016.1262516; Chune Young Chung, Sangjun Jung, and Jason Young, "Do CSR Activities Increase Firm Value? Evidence from the Korean Market," Sustainability 10, no. 9 (2018): 3164, https://doi.org/10.3390/su10093164; Hassan M. Hafez, "Corporate Social Responsibility and Firm Value: An Empirical Study of an Emerging Economy," Journal of Governance and Regulation 5, no. 4 (2016): 40-53, https://doi.org/10.22495/jgr_v5_i4_p3; Woo Sung Kim and Sekyung Oh, "Corporate Social Responsibility, Business Groups and Financial Performance: A Study of Listed Indian Firms," Economic Research-Ekonomska Istraživanja 32, no. 1 (2019): 1777-93, https://doi.org/10.1080/1331677X.2019.1637764; Lars Moratis, "Signalling Responsibility? Applying Signalling Theory to the ISO 26000 Standard for Social Responsibility," Sustainability 10, no. 11 (2018): 4172, https://doi.org/10.3390/su10114172.

${ }^{5}$ Helma Malini, "Determinants of Shariah Banking Performances in Indonesia Through the Perspective of Economic and Social Level," Jurnal Ekonomi Bisnis Dan Kewirausahaan (JEBIK) 9, no. 1 (2020): 47-57, https://doi.org/10.26418/jebik.v9i1.34327.

${ }^{6}$ Jasser Auda, Maqasid Al-Shariah as Philosophy of Islamic Law: A Systems Approach (International Institute of Islamic Thought (IIIT), 2008): 1-347.

7 Akhmad Nur Zaroni, "Landasan Filosofis Perilaku Konsumen Dalam Perspektif Ekonomi Islam Dan Konvensional," Mazahib 10, no. 1 (2012): 55-68, https://doi.org/https://doi.org/10.21093/mj.v10i1.110; Jonathan A J Wilson, "The Halal Phenomenon: An Extension or a New Paradigm?," Social Business 4, no. 3 (2014): 255-71, https://doi.org/10.1362/204440814X14103454934294; Irwan Misbach, "Perilaku Bisnis Syariah," Al-Idarah 5 (2017): 33-44; Muhamad Nadratuzaman Hosen and Fitriyani Lathifah, "Comparison of Halal Certification in Several Countries toward Halal Standard of Indonesia," in Proceedings of the 1st International Conference on Recent Innovations (ICRI 2018), 2018, 201-10, https://doi.org/10.5220/0009921502010210; Iwan Satriyo Nugroho, Tombak Gapura Bhagya, and Dian Rosinawati, "Industri Dan Supply Chain Halal Dilihat Dari Aspek Keilmuan Teknik Industri," Sainteks: Jurnal Sains Dan Teknik 2, no. 2 (2020): 58-71.
} 
Several theories formed the basis of CSR, namely the theory of corporate accountability, stakeholders, legitimacy, corporate sustainability, political economy and justice. The debate on these theories revolves around whether the CSR concept should become voluntarily or compulsory. The debate phenomenon that assesses CSR as a financial burden and a strategic investment has prompted much research on how CSR implementation impacts company performance and value. In theory, CSR implementation is an effort to internalise various externalities from community activities oriented toward economic and social interests. In practice, companies that implement CSR have various perspectives. ${ }^{8}$ Green banking has a significant role in sustainable development to overcome institutional and market challenges. For Islamic banking, green banking allocates investment into green projects and green finance. Green finance involves Islamic bank strategic and operating plans that consider projects that could generate sustainability. ${ }^{9}$

Islamic bank being sustains characterised with intrinsic moral dimension and its moral responsibility. In principles, Islamic banking should comply with ethics and obey rules in Shariah principle. The Islamic bank concept contributes to reducing systemic risk. However, the sustainability concept applies in green banking, which develops around plant and waste management. In contrast, risk-sharing is a unique concept that enables an investor to share risk. The concept integrated with the conventional counterpart is only pursuing profit in several of Indonesia's Islamic banking. ${ }^{10}$ Thus the Maqasid Al-Shariah concept also depends on good corporate governance, fairness, transparency and accountability in Islamic banks to achieve sustainability. This concept is best suited to Islamic banking by implementing CSR and green finance following the Maqasid Al-Shariah framework. ${ }^{11}$

The existing literature could not capture systematic business practices based on Shariah or Islamic principles integrated into conventional charged CSR practices. Hence, the study aims to map the ideal format for CSR in Islamic and conventional banks by investigating and expanding on its implications for green finance. ${ }^{12}$ This study examines Islamic banks'

\footnotetext{
${ }^{8}$ Mahmoud A. El-Gamal, Islamic Finance: Law, Economics, and Practice, 1st ed. (Cambridge: Cambridge University Press, 2006): 1-221.

${ }^{9}$ Bassam Maali, Peter Casson, and Christopher Napier, "Social Reporting by Islamic Banks," Abacus 42, no. 2 (2006): 266-89, https://doi.org/10.1111/j.1467-6281.2006.00200.x.

${ }^{10}$ M. Umer Chapra, "The Case against Interest: Is It Compelling?," Thunderbird International Business Review 49, no. 2 (2007): 161-86, https://doi.org/10.1002/tie.20138; Beng Soon Chong and Ming-Hua Liu, "Islamic Banking: Interest-Free or Interest-Based?," Pacific-Basin Finance Journal 17, no. 1 (2009): 125-44, https://doi.org/10.1016/j.pacfin.2007.12.003; Humayon A. Dar and John R. Presley, "Lack of Profit-Loss Sharing in Islamic Banking: Management and Control Imbalances," International Journal of Islamic Financial Services 2, no. $\quad 2 \quad$ (2000): 2 3-18, https://citeseerx.ist.psu.edu/viewdoc/download?doi=10.1.1.196.5571\&rep=rep1\&type=pdf; $\quad$ Sayd Farook, "Social Responsibility for Islamic Financial Institutions: Laying Down a Framework," Journal of Islamic Economics, Banking and Finance 4, no. 1 (2008): 61-82; Tarik M. Yousef, "The Murabaha Syndrome in Islamic Finance: Laws, Institutions and Politics," The Politics of Islamic Finance, 2004, 63-80, https://doi.org/10.3366/edinburgh/9780748618361.003.0003.

${ }^{11}$ Zakaria Aribi and Simon Gao, "Narrative Disclosure of Corporate Social Responsibility in Islamic Financial Institutions," Managerial Auditing Journal 27, no. 2 (2011): 199-222, https://doi.org/10.1108/02686901211189862; Roszaini Haniffa and Mohammad Hudaib, "Exploring the Ethical Identity of Islamic Banks Via Communication in Annual Reports," Journal of Business Ethics 76, no. 1 (2007): 97-116, https://doi.org/10.1007/s10551-006-9272-5; Abul Hassan and Sofyan Syafri Harahap, "Exploring Corporate Social Responsibility Disclosure: The Case of Islamic Banks," International Journal of Islamic and Middle Eastern Finance and Management 3, no. 3 (2010): 203-27, https://doi.org/10.1108/17538391011072417; Maali, Casson, and Napier, "Social Reporting by Islamic Banks"; Azhar Abdul Rahman, Mohd Farid Asraf Md Hashim, and Fathiyyah Abu Bakar, "Corporate Social Reporting: A Preliminary Study of Bank Islam Malaysia Berhad (BIMB)," Issues in Social and Environmental Accounting 4, no. 1 (2010): 18-39, https://doi.org/10.22164/isea.v4i1.45.

12 Hassan and Harahap, "Exploring Corporate Social Responsibility Disclosure: The Case of Islamic Banks."
} 
sustainability in Indonesia by implementing CSR and green finance with the Shariah principle accountability and achieving three pillars of sustainability (people, profit and environment). Islamic bank needs to be sustainable while also achieving Maqasid Al-Shariah.

Sustainability in banking often refers to sustainable investing or Socially Responsible Investing (SRI), where investment delivers to specific projects that are proven to be sustainable. ${ }^{13}$ The concept is not merely about investing but more about how a bank could deliver sustainability. Sustainability points are customer satisfaction, good profitability, superior performance in the medium and long-term, and a contribution to the whole financial system by controlling and monitoring risk levels. ${ }^{14}$ In contrast to the current developing theory, implementing sustainability is by implementing CSR. According to Shariah principles, the CSR concept is more than wanting to get a positive image and long-term impact but rather to the dimensions of service to God, environment and society. CSR includes law, morals, and justice, manifesting as human obedience to God in Islam's view. ${ }^{15}$ This manifestation is responsibly in the form of contributing to society's well-being, ${ }^{16}$ where the final goal is to Falah (human well-being) and Hayat Tayyibah (the good life). ${ }^{17}$

CSR developed into a concept integrated with business concepts aligned with sharia principles for Islamic banking. These principles are compliance toward transparency, responsibility and justice. ${ }^{18}$ In conventional economics, the pursuit of profit is the main objective for companies to maintain sustainability. In Islam, profits achievement are allowed, but the process should be under Islamic values. ${ }^{19}$ In the current development of the CSR concept, its implementation is often associated with allocating funds to the community as a charity. ${ }^{20}$ However, criticisms are given to Islamic banking related to CSR implementation, which prioritises profit rather than impacting society and the environment.

Data used in this research are collected from 34 units of Islamic banks in Indonesia (including the conventional bank with Islamic banks unit) through Bank data, Indonesian Central bank and IMF research database over the period 2011-2019. Financial statements of Islamic banks that operate in Indonesia are collected from each financial report. The analysis method in this study used multivariate statistical methods, structural equation modelling with

\footnotetext{
${ }^{13}$ Marcel Jeucken, "Sustainable Finance and Banking-Slow Starters Are Gaining Pace," in Sustainable Finance and Banking: The Financial Sector and the Future of the Planet (Oxfordshire: Routledge, 2001): 1-336.

${ }^{14}$ Sana Ben Abdallah, Dhafer Saïdane, and Mehrez Ben Slama, "CSR and Banking Soundness: A Causal Perspective," Business Ethics: A European Review 29, no. 4 (2020): 706-21, https://doi.org/10.1111/beer.12294.

15 Maria-Gaia Soana, "The Relationship between Corporate Social Performance and Corporate Financial Performance in the Banking Sector," Journal of Business Ethics 104, no. 1 (2011): 133, https://doi.org/10.1007/s10551-011-0894-x.

${ }^{16}$ Haniffa and Hudaib, "Exploring the Ethical Identity of Islamic Banks Via Communication in Annual Reports."

17 Samir Abderrazek Srairi, "Factors Influencing the Profitability of Conventional and Islamic Commercial Banks in GCC Countries," Review of Islamic Economics 13, no. 1 (2009): 5-30.

${ }^{18}$ Mehmet Asutay and Hylmun Izhar, "Estimating the Profitability of Islamic Banking: Evidence from Bank Muamalat Indonesia," Review of Islamic Economics 11, no. 2 (2007): 17-29, https://papers.ssrn.com/sol3/papers.cfm?abstract_id=1735651; Francesco Gangi, Mario Mustilli, and Nicola Varrone, "The Impact of Corporate Social Responsibility (CSR) Knowledge on Corporate Financial Performance: Evidence from the European Banking Industry," Journal of Knowledge Management 23, no. 1 (2019): 110-34, https://doi.org/10.1108/JKM-04-2018-0267; Eliada Herwiyanti, Ratu Ayu Sri Wulandari MA, and Ayu Amrina Rosada, "Analysis of Factors Influencing the Islamic Corporate Governance Disclosure Index of Islamic Banks in Asia," International Journal of Humanities and Management Science (IJHMS) 3, no. 4 (2015): 1-6; Malini, "Determinants of Shariah Banking Performances in Indonesia Through the Perspective of Economic and Social Level."

19 Rania Kamla, "Critically Appreciating Social Accounting and Reporting in the Arab MiddleEast: A Postcolonial Perspective," Advances in International Accounting 20, no. 8 (2007): 105-77, https://doi.org/10.1016/S0897-3660(07)20005-4.

${ }^{20}$ Maali, Casson, and Napier, "Social Reporting by Islamic Banks."
} 
WarpPLS software program and testing panel data regression models using E-Views software program. The multivariate analysis is a simultaneous analysis of several variables in one or more relationships using two or more variables as composite indicators. Structural equation modelling is an analytical technique that allows different relationships for each dependent variable.

The data collected is then analysed by describing the data without making general conclusions. The descriptive analysis provides an overview of the independent variables, dependent variables, intervening variables and moderating variables used in this study. Model fit testing was conducted to assess whether the data in this study were consistent and fit the model. If the model matches the data, it means that the model is aligned in determining the degree of suitability.

This research investigates the short and long-run relationship among CSR with ten selected variables. The research estimates them by GMM estimation, where the error correction terms are incorporated in the models. The GMM could estimate the model parameters and test the moment conditions that arise during research. Study on five variables Johansen-Juselius co-integration test, the VECM representation could then be reformulated in a simple matrix form as follows: ${ }^{21}$

$$
\left[\begin{array}{l}
\Delta U F C V \\
\Delta U M C V \\
\Delta U C C V \\
\Delta C A T A R \\
\Delta D R \\
\Delta U F F P \\
\Delta U M F P \\
\Delta U C F P \\
\Delta C S R I \\
\triangle D C S R
\end{array}\right]=\left[\begin{array}{l}
\delta 0 \\
\delta 1 \\
\delta 2 \\
\delta 3 \\
\delta 4 \\
\delta 5 \\
\delta 6 \\
\delta 7 \\
\delta 8 \\
\delta 9 \\
\delta 10
\end{array}\right]+\sum_{i=1}^{K} r i\left[\begin{array}{l}
\Delta U F C V \\
\Delta U M C V \\
\Delta U C C V \\
\Delta C A T A R \\
\Delta D R \\
\Delta U F F P \\
\Delta U M F P \\
\Delta U C F P \\
\Delta C S R I \\
\Delta D C S R
\end{array}\right] \mathrm{t}-\mathrm{k}+\left[\begin{array}{l}
U F C V \\
U M C V \\
U C C V \\
C A T A R \\
D R \\
U F F P \\
U M F P \\
U C F P \\
C S R I \\
D C S R
\end{array}\right] \mathrm{t}-1+\left[\begin{array}{l}
v 0 \\
v 1 \\
v 2 \\
v 3 \\
v 4 \\
v 5 \\
v 6 \\
v 7 \\
v 8 \\
v 9 \\
v 10
\end{array}\right]
$$

The information criterion (AIC) is used to determine the lag length incorporation in the entire tests in this research. It is important to note that for the GMM estimator to be identified, there should be at least as many instrumental variables $Z$ as there are parameters $\Theta .{ }^{22}$ This study used lags of explanatory variables as the instrumental variables. This variable was opted for use because of the difficulty finding other instrument variables, as the research utilises daily data for an extended period.

Table 1. Summarisation of Research Variable

\begin{tabular}{|c|c|c|c|}
\hline Variable & Approach & Proxy & Indicator \\
\hline \multirow{3}{*}{ Firm Value } & Fundamental & UFCV & $=\frac{\text { Equity }_{\mathrm{t}}-\text { Equity }_{\mathrm{t}-1}}{\text { Equity }_{\mathrm{t}-1}} \times 100 \%$ \\
\cline { 2 - 4 } & Market & $\mathrm{UMCV}$ & $=\frac{\mathrm{MCAP}_{\mathrm{t}}-\mathrm{MCAP}_{\mathrm{t}-1}}{\mathrm{MCAP}_{\mathrm{t}-1}} \times 100 \%$ \\
\cline { 2 - 4 } & Comprehensive & $\mathrm{UCCV}$ & $=\frac{\mathrm{PBV}_{\mathrm{t}}-\mathrm{PBV}_{\mathrm{t}-1}}{\mathrm{PBV}_{\mathrm{t}-1}} \times 100 \%$ \\
\hline
\end{tabular}

${ }^{21}$ Bill Wan-Sing Hung and Yan-Leung Cheung, "Interdependence of Asian Emerging Equity Markets," Journal of Business Finance \& Accounting 22, no. 2 (2006): 281-288, https://doi.org/10.1111/j.14685957.1995.tb00684.x.

${ }^{22}$ H Akaike, "A New Look at the Statistical Model Identification," IEEE Transactions on Automatic Control 19, no. 6 (1974): 716-23, https://doi.org/10.1109/TAC.1974.1100705. 


\begin{tabular}{|c|c|c|c|}
\hline \multirow{3}{*}{ Financial Decisions } & $\begin{array}{l}\text { Operational } \\
\text { Decisions }\end{array}$ & $\mathrm{OC}$ & $=\operatorname{Ln} \sum$ Operational Fee \\
\hline & $\begin{array}{l}\text { Investment } \\
\text { Decisions }\end{array}$ & QATAR & $=\frac{\text { Current Asset }}{\text { Total Asset }}$ \\
\hline & Funding Decision & DR & $=\frac{\text { Total Debt }}{\text { Total Asset }}$ \\
\hline \multirow{3}{*}{$\begin{array}{c}\text { Financial } \\
\text { Performances }\end{array}$} & Fundamental & AFP & $=\frac{\mathrm{EBIT}_{\mathrm{t}}-\mathrm{EBIT}_{\mathrm{t}-1}}{\mathrm{EBIT}_{\mathrm{t}-1}} \times 100 \%$ \\
\hline & Market & AFP & $=\frac{\mathrm{SP}_{\mathrm{t}}-\mathrm{SP}_{\mathrm{t}-1}}{\mathrm{SP}_{\mathrm{t}-1}} \times 100 \%$ \\
\hline & Comprehensive & UCFP & $=\frac{\mathrm{PER}_{\mathrm{t}}-\mathrm{PER}_{\mathrm{t}-1}}{\mathrm{PER}_{\mathrm{t}-1}} \times 100 \%$ \\
\hline \multirow{2}{*}{$\begin{array}{c}\text { Green } \\
\text { Finance }\end{array}$} & \multirow{2}{*}{ CSR } & CSRI & 78 Index of CSR \\
\hline & & DCSR & Certificate ISO 14001 \\
\hline
\end{tabular}

The empirical model used to test the hypothesis consists of four main models:

1. Research model to test the hypothesis H1

To test hypothesis 1 , which predicts the relationship between financial decisions and financial performance on firm value, equation (1) uses the primary panel data regression as follows:

$$
\mathrm{CV}=\alpha 0+\beta 1 \mathrm{OCit}+\beta 2 \mathrm{CATARit}+\beta 3 \mathrm{DRit}+\beta 4 \mathrm{UFFPit}+\beta 5 \mathrm{UMFPit}+\beta 6 \mathrm{UCFPit}+\varepsilon
$$

To examine the effect of financial decisions and financial performance on firm value as measured by three different proxies, the advanced regression model from equation (1) is as follows:

$$
\begin{aligned}
& \mathrm{UFCV}=\alpha 0+\beta 1 \mathrm{OC} \mathrm{it}^{+}+\beta 2 \mathrm{CATARit}+\beta 3 \mathrm{DRit}+\beta 4 \mathrm{UFFPit}+\beta 5 \mathrm{UMFPit}+\beta 6 \mathrm{UCFPit}+\varepsilon \text { (1a) } \\
& \mathrm{UMCV}=\alpha 0+\beta 1 \mathrm{OC} \text { it }+\beta 2 \text { CATARit }+\beta 3 \text { DRit }+\beta 4 \text { UFFPit }+\beta 5 \text { UMFPit }+\beta 6 \text { UCFPit }+\varepsilon(1 \mathrm{~b}) \text { UCCV } \\
& =\alpha 0+\beta 1 \mathrm{OC}_{\mathrm{it}}+\beta 2 \mathrm{CATARit}+\beta 3 \mathrm{DR} \mathrm{it}+\beta 4 \mathrm{UFFPit}+\beta 5 \mathrm{UMFPit}^{+} \beta 6 \mathrm{UCFPit}+\varepsilon(1 \mathrm{c})
\end{aligned}
$$

2. Research model to test the hypothesis $\mathrm{H} 2$

To test hypothesis 2, which predicts the relationship between financial decisions and financial performance, equation (2) uses the primary panel data regression as follows:

$$
\mathrm{FP}=\alpha 0+\beta 1 \mathrm{OC}_{\mathrm{it}}+\beta 2 \mathrm{CATARit}+\beta 3 \mathrm{DR}_{\mathrm{it}}+\varepsilon
$$

To test the effect of financial decisions on financial performance as measured by three different proxies, the advanced regression model from equation (2) is as follows:

$$
\begin{aligned}
& \mathrm{UFFP}=\alpha 0+\beta 1 \mathrm{OCit}^{+} \beta 2 \mathrm{CATARit}+\beta 3 \mathrm{DR} i \mathrm{t}+\varepsilon(2 \mathrm{a}) \\
& \mathrm{UMFP}=\alpha 0+\beta 1 \mathrm{OC}^{+}+\beta 2 \mathrm{CATARit}+\beta 3 \mathrm{DRit}+\varepsilon(2 \mathrm{~b}) \\
& \mathrm{UCFP}=\alpha 0+\beta 1 \mathrm{OCit}^{+} \beta 2 \mathrm{CATARit}^{+} \beta 3 \mathrm{DR} i \mathrm{t}+\varepsilon(2 \mathrm{c})
\end{aligned}
$$

3. Research model to test the hypothesis H3

Testing hypothesis 3 examines the mediating effect of financial performance on financial decisions and firm value. The analysis is carried out by calculating the path coefficient of equations (1) and equation (2). 
4. Research model to test the hypothesis H4

To test hypothesis 4, which tests the moderating effect of green finance on financial decisions and firm value, equation (4) uses the primary panel data regression as follows:

\section{$\mathrm{CV}=\alpha 0+\beta 1 \mathrm{OC} i \mathrm{t}+\beta 2 \mathrm{CATARit}+\beta 3 \mathrm{DRit}+\beta 4 \mathrm{OC} \mathrm{it}^{*} \mathrm{GFit}^{+} \beta 5 \mathrm{CATAR} \mathrm{Ri}^{*} \mathrm{GFit}^{+} \beta 6 \mathrm{DR} \mathrm{it}^{*} \mathrm{GFit}^{+} \varepsilon$}

To test the effect of the moderating effect of green finance on financial decisions and firm value as measured by three different proxies, the advanced regression model from equation (4) is as follows:

\section{$\mathrm{UFCV}=\alpha 0+\beta 1 \mathrm{OC} \mathrm{it}^{+} \beta 2 \mathrm{CATAR} \mathrm{it}^{+} \beta 3 \mathrm{DR} \mathrm{it}+\beta 4 \mathrm{OC} \mathrm{it} * \mathrm{GFit}^{+}+\beta 5 \mathrm{CATAR} \mathrm{it}^{*} \mathrm{GFit}^{+} \beta 6 \mathrm{DR}_{\mathrm{it}} * \mathrm{GFit}^{+} \varepsilon$}

$\mathrm{UMCV}=\alpha 0+\beta 1 \mathrm{OC} \mathrm{it}^{+}+\beta 2 \mathrm{CATARit}+\beta 3 \mathrm{DRit}+\beta 4 \mathrm{OCit}{ }^{*} \mathrm{GFit}+\beta 5 \mathrm{CATARit} * \mathrm{GFit}+\beta 6 \mathrm{DRit} * \mathrm{GFit}+\varepsilon$

$\mathrm{UCCV}=\alpha 0+\beta 1 \mathrm{OC} i \mathrm{t}+\beta 2 \mathrm{CATARit}+\beta 3 \mathrm{DRit}+\beta 4 \mathrm{OCit} * \mathrm{GFit}+\beta 5 \mathrm{CATARit} * \mathrm{GFit}^{+}+\beta 6 \mathrm{DRit} * \mathrm{GFit}+\varepsilon$ $(4 \mathrm{c})$

\section{B. Discussion}

Table 2. Preliminary Analysis

\begin{tabular}{|c|c|c|c|c|c|c|}
\hline & Observ. & Mean & t-stats & Var. & Skewness & $\begin{array}{c}\text { Standard } \\
\text { Deviation }\end{array}$ \\
\hline UFCV & 220 & 1.0786 & 5.23403 & 14.6055 & 8.57324 & 0.03972 \\
\hline UMCV & 220 & 1.1750 & 50.8800 & 14.8930 & 3.55500 & 0.06000 \\
\hline UCCV & 220 & 17.7800 & 789.240 & 18.1281 & 100.000 & 1.72000 \\
\hline OC & 220 & -23.6600 & 13.4000 & 10.7166 & 0.00000 & -1.5700 \\
\hline QATAR & 220 & 1.29320 & 66.3451 & 1.4638 & 0.8463 & 11.243 \\
\hline DR & 220 & -1.89712 & 78.4321 & -0.2426 & 3.81701 & 0.01808 \\
\hline AFP & 220 & 8.6890 & 3.7654 & 1.7689 & 1.4220 & 5.7654 \\
\hline AFP & 220 & -0.3918 & 0.226 & 0.3597 & 10.653 & 12.1174 \\
\hline UCFP & 220 & 9.9654 & 6.2867 & 13.8795 & 0.0000 & 10.000 \\
\hline CSRI & 220 & -0.3700 & 45.000 & 50.000 & 45.000 & 50.000 \\
\hline
\end{tabular}

Funding Decisions (78.4321) translates as the ability of Islamic banks in Indonesia to conduct investment decisions, including choosing the best platform to invest in. In terms of firm's values perspectives, the fundamental approach's average mean is positive, contributing to Islamic banks' performances in Indonesia. Investment decisions contribute to the risk exposure of Islamic banks, particularly related to credit schemes delivered to the customer. Optimal funding decisions in Islamic banks are when they could perform by maximising the use of its asset.

The highest standard deviation value is $\mathbf{1 2 . 1 1 7 4}$ at UMFP, translating to market financial performance. In the Islamic Banking industry, credit risk contributes significantly to market performances achievement since most of the financing fund applied is credit transfer in Murabaha and Musyarakah. In the implementation, Murabaha and Musyarakah have risks in paying credit funds. On the contrary, the highest standard deviation follows a lower fundamental financial performance value (5.7654). Suppose the standard deviation in one country exceeds the threshold of 3 . In that case, the performances have "fatter tails" than expected from a normally distributed variable, where Islamic banks in Indonesia are generally 
profitable. Still, the circumstances depend on many factors, including the domination in Islamic banking market share.

Table 3. Analysis results of the correlations between pairs of variables

\begin{tabular}{|c|c|c|c|c|c|c|c|c|c|c|}
\hline & UFCV & UMCV & UCCV & OC & $\begin{array}{c}\text { QATA } \\
\text { R }\end{array}$ & DR & AFP & AFP & UCFP & CSRI \\
\hline UFCV & 1.000 & & & & & & & & & \\
\hline UMCV & 0.430 & 1.000 & & & & & & & & \\
\hline UCCV & 0.312 & 0.341 & 1.000 & & & & & & & \\
\hline OC & 0.241 & 0.453 & 0.031 & 1.000 & & & & & & \\
\hline QATAR & -0.222 & -0.456 & 0.674 & -0.765 & 1.000 & & & & & \\
\hline DR & 0.431 & 0.789 & 0.563 & 0.876 & 0.765 & 1.000 & & & & \\
\hline AFP & 0.061 & -0.090 & -0.115 & $-0.184 * *$ & 0.052 & 0.039 & 1.000 & & & \\
\hline AFP & 0.000 & 0.018 & 0.472 & -0.140 & 0.034 & 0.015 & 0.861 & 1.000 & & \\
\hline UCFP & 0.651 & 0.321 & 0.321 & 0.654 & 0.920 & 0.983 & 0.765 & 0.272 & 1.000 & \\
\hline CSRI & 0.364 & & 0.431 & 0.654 & 0.928 & 0.632 & 0.769 & 0.982 & $0.149 * *$ & 1.000 \\
\hline
\end{tabular}

Table 3 showed that all selected Islamic banks showed a strong correlation with selected variables during the period of observation. Strong correlation or the highest value of correlation is recorded between Operational and Funding decisions (0.876), followed by Market Value and funding decisions (0.789) and Investment decisions with funding decisions (0.765). The strong correlation between these variables suggests that funding decisions contribute to operational decisions, investment decisions, and market values, making Islamic banking in Indonesia carefully assess every funding policy implemented.

This result suggests that sustainability achievement in Islamic banks is determined by its capabilities in maximising funding decisions toward the financing concept. The Mudharaba model should focus on financing projects or activities with a longer lucrative cycle. The Murabaha model should focus on social welfare and reduce poverty by adopting microfinance services.

Table 4. Regression Analysis (Dependent Variable: Logarithmic Return)

\begin{tabular}{|c|c|c|c|c|}
\hline & Coefficient & Std. Error & t-ratio & p-value \\
\hline Intercept (C) & -0.0332656 & 0.0214116 & -0.5163 & 0.26295 \\
\hline UFCV & -0.0233915 & 0.0325412 & -0.6374 & 0.41281 \\
\cline { 3 - 5 } UMCV & 0.0312119 & & 0.2205 & 0.42111 \\
UCCV & -0.0112227 & 0.0125851 & -0.0612 & 0.83204 \\
OC & -0.0313121 & 0.0140731 & -1.0508 & 0.25460 \\
QATAR & -0.0233192 & 0.0340714 & -0.4865 & 0.65810 \\
DR & 0.0120816 & 0.0060752 & 0.7944 & 0.48119 \\
AFP & 0.0454851 & 0.693472 & -0.1163 & 0.59969 \\
AFP & -0.0232023 & 0.0342541 & -0.0140 & 0.88991 \\
UCFP & 0.0480856 & 0.0340752 & 1.0432 & 0.20911 \\
CSRI & -0.0310151 & -0.0340752 & -0.7100 & 0.35473 \\
R-squared & 0.1321742 & 0.0360752 & Adjusted R-squared & 0.02225 \\
\cline { 3 - 4 } & & & &
\end{tabular}

Note: *** indicates significant at $1 \%$ level; ** indicates significant at 5\% level; * indicates significant at $10 \%$ level.

The regression analysis is conducted using separate model variables: corporate value, financial decisions, and financial performances. The natural logarithm of CSR has been used as a moderation proxy where the proxy for firm value is Fundamental (UFCV), Market (UMCV) and Comprehensive (UCCV). For Financial decisions, the proxy is Operational Decision (OC), Investment Decision (CATAR) and Funding Decision (DR). Furthermore, 
financial performances proxy would be Fundamental (UFFP), Market (UMFP) and Comprehensives (UCFP), and the last one for Green Finance the proxy would be CSR (CSRI and DCSR).

The result showed that CSRI has a less significant impact on Market Value (UMCV), Funding Decisions (DR), Fundamental Value (UFFP) and Comprehensive Value (UCFP) of Islamic Banking in Indonesia showed by the value of $\mathrm{R}$-squared (0.1321742). The result implies that Islamic banks in Indonesia are interested in applying CSR to gain market value, fundamental value and total value through their funding decisions. The result is also parallel with the sustainability theory, where companies performing CSR activities would gain longterm benefits in increasing corporations' value. The Islamic banking sustainability paradigm in terms of funding decisions focusing on the Islamic provision and ethics with the main framework to avoid harm and consequently promote the wealth of society wherein the beginning of the implementation to alleviate poverty and reduce inequality. ${ }^{23}$ On the other side, Islamic banks should promote sustainable financial instruments to benefit society. ${ }^{24}$ Table 4 also showed that there are six negative variables. This result implies that value is Fundamental, Comprehensive, Operational Decision, Investment Decision and Financial Comprehensives deliver less impact toward the sustainability of Islamic banking.

Risk-sharing characteristics focus on fairness, ethics investment and avoiding speculative activities in a financial transaction that could be achieved by providing an Islamic banking model based on Shariah principal norm. Thus, Islamic banks should only offer products that comply with Shariah and are sustainable. However, this practice deviates from the origin and focuses on profit. ${ }^{25}$ While, on several examples, Islamic banks tend to act and resemble conventional banks, thus achieving sustainability becoming elusive. Islamic banking in Indonesia is required to become sustainable not only for the Single Bottom Line, i.e. financial condition but also for the Triple Bottom Lines. This would be required by law, as the government may change the regulations and force Islamic banks to adapt.

Table 5. Model Estimation

\begin{tabular}{|c|c|c|c|c|}
\hline Variables & $\begin{array}{c}\text { Fixed } \\
\text { Effects }\end{array}$ & $\begin{array}{c}\text { Random } \\
\text { Effects }\end{array}$ & $\begin{array}{c}\text { 1st step } \\
\text { Differenced } \\
\text { GMM }\end{array}$ & $\begin{array}{c}\text { 2nd Step } \\
\text { Differenced } \\
\text { GMM }\end{array}$ \\
\hline UFCV & -0.0196 & 0.3576 & 1.2512 & 0.02024 \\
\hline UMCV & -0.0213 & 0.1183 & -2.8137 & 0.01278 \\
\hline UCCV & 0.0031 & 0.3233 & 0.0844 & 0.00872 \\
\hline OC & -0.0035 & 0.2238 & -0.2885 & 0.01100 \\
\hline QATAR & 0.0163 & 0.2396 & 1.0748 & 0.01416 \\
\hline DR & 0.0509 & 0.2879 & 1.0064 & 0.01395 \\
\hline AFP & -0.0081 & 0.1869 & 0.6904 & 0.01286 \\
\hline UMFP & 0.0109 & 0.1696 & 0.016 & 0.01931 \\
\hline UCFP & 0.0251 & 0.3279 & 2.7519 & 0.00986 \\
\hline CSRI & 0.0322 & 0.5692 & 2.9903 & 0.01483 \\
\hline R-squared & 0.0191 & 0.2545 & 0.6453 & -0.0804 \\
\hline
\end{tabular}

\footnotetext{
${ }^{23}$ Aliyu et al., "Islamic Banking Sustainability: A Review of Literature and Directions for Future Research"; Amin Jan and Maran Marimuthu, "Bankruptcy and Sustainability: A Conceptual Review on Islamic Banking Industry," Global Business \& Management Research 7, no. 1 (2015): 109-38, http://www.gbmrjournal.com/pdf/vol. 7 no. 1/V7N1-7-Jan and Marimuthu.pdf.

${ }^{24}$ Yao Wang and Qiang Zhi, "The Role of Green Finance in Environmental Protection: Two Aspects of Market Mechanism and Policies," Energy Procedia 104 (2016): 311-316, https://doi.org/10.1016/j.egypro.2016.12.053.

${ }^{25}$ Mehmet Asutay, "Conceptualizing and Locating the Social Failure of Islamic Finance: Aspirations of Islamic Moral Economy vs the Realities of Islamic Finance,” Asian and African Area Studies 11, no. 2 (2012): 93-113, https://doi.org/10.14956/asafas.11.93.
} 


\begin{tabular}{|c|c|c|c|c|}
\hline F-stat/ Wald- $\chi^{2}$ & -0.0046 & 0.1239 & -2.6359 & -0.8530 \\
\hline AR(1) test & 4.2594 & 1.8952 & 2.3908 & 0.3974 \\
\hline AR(2) test & 0.4839 & 0.4315 & 0.7894 & 0.0211 \\
\hline No. observations & 220 & 220 & 220 & 220 \\
\hline
\end{tabular}

The results from table 5 describe that at least two variables significantly influence Islamic banks: investment decisions and market performances. This result translated as a plausible positive direction of influence where Islamic banks performances would affect investment and market value. However, a high level of investment increases high operational costs and weakens the growth of Islamic banks as an industry. Referring to the impact of credit risk is found that positive and significant impact on the profitability of Islamic banks even at 5\% level. The result implies that an increase and decrease in credit risk would influence the performances and value of Islamic banks.

Table 5 results could confirm a significant relationship between financial decisions, financial performance and corporate value of Islamic banks. Islamic bank has to thoroughly assess it because its main activities focus on borrowing funds and financing. Islamic bank transactions in the form of sale-purchase (Murabaha, Istisna, and Salam), investment (Musyarakah/Mudharabah/Musyarakah Mutanaqisah), rent (Ijarah/Al-Ijarah Al-Muntahiyah Bi Al-Tamlik), and the provision of other services such as (Wakalah bil Ujrah) guarantee (Kafalah) should be conducted by fulfilling the provisions of Islamic law. Provisions of Islamic law include the principles of justice and balance ('adl was tawazun), welfare (maslahah), and universalism (alamiyah) and does not contain gharar, maysir, riba, dzalim, riswah, and haram objects. ${ }^{26}$

When Islamic banking implements CSR indirectly, the company has also complied with government regulations. In Indonesia, obligations related to the responsibilities of a company are regulated in Law No. 40 of 2007 concerning Limited Liability Companies and Government Regulation No. 47 of 2012 concerning Social and Environmental Responsibility of Limited Liability Companies. Article 74 paragraph 1 of Law No. 40 of 2007 states that "Companies that carry out their business activities in the field of and or related to natural resources are obliged to carry out social and environmental responsibilities". While in Article 2 Government Regulation No. 47 of 2012 states that "Every company as a legal subject has social and environmental responsibilities".

Islamic that ignores social responsibility is not complying with government regulations. This could have a severe impact on the sustainability and success of the company's business in the future. Companies that do not carry out CSR are more likely to have a bad image socially and environmentally. The company would face the law for not complying with the laws and regulations. Protests and rejection by the community who feel disadvantaged by the company's existence because of the environmental impact it causes are also unavoidable. Another impact, the company could lose because consumers prefer competitors who carry out CSR well. In Indonesia, Corporate Social Responsibility (CSR) is strictly regulated by Law No. 40 of 2007 concerning Limited Liability Companies. There are four legal reasons for this regulation. These reasons include philosophical, juridical, sociological, and historical reasons. Furthermore, Indonesia is a country that implements corporate social responsibility implicitly.

\footnotetext{
${ }^{26}$ Syed Asim Ali Bukhari et al., "Green Banking and Islam: Two Sides of the Same Coin," Journal of Islamic Marketing 11, no. 4 (2019): 977-1000, https://doi.org/10.1108/JIMA-09-2018-0154; Habib Ahmed et al., Handbook of Islamic Banking, ed. M. Kabir Hassan and Mervyn K. Lewis (Cheltenham: Edward Elgar Publishing, 2009): 464, https://doi.org/10.4337/9781847205414; Mohammad Masukujjaman et al., "Bankers' Perception of Green Banking: Learning from the Experience of Islamic Banks in Bangladesh," Geografia: Malaysian Journal of Society and Space 12, no. 2 (2016): 144-53, http://www.ukm.my/geografia/images/upload/13x.geografia-si-feb16-shahalam-edam (1).pdf.
} 
Corporate social responsibility is governed by law. Thus, corporate social responsibility could be voluntary or mandated by the government.

\section{Conclusion}

The path to sustainability is challenging as the global economy grapples with risks and consequences. Islamic banking should address sustainability and climate change by providing a process and system in materiality, data transparency, risk and return, and capacity building that is appropriately integrated into the financial system. This study revises and constructs the CSR implementation with green finance toward Islamic bank value, performances and financial decisions. The findings showed that there is a high correlation between operational and funding decisions (0.876), market value and funding decisions (0.789) and investment decisions with funding decisions (0.765). The strong correlation between these variables implies that an Islamic bank in Indonesia should focus more on its funding policy. In Islamic banking, capabilities to choose finance projects in the scope of green finance and green investments are widely open.

GMM model estimation showed a positive influence between Islamic bank performances toward investment and market value. Based on the result, policymakers in Islamic banking should focus on creating investment freedom for Islamic banking to finance projects or activities under green finance and flexibility to perform and allocate funds from a CSR interpretation of CSR that is more than charity. This result would also influence whether CSR should translate into a higher allocation of funding or strengthen the existing CSR program since it would make distinctive differences. Nevertheless, Islamic banks should cater to the needs toward sustainability in the form of CSR and green finance and through an integrated sustainability program and system.

\section{REFERENCES}

Abdallah, Sana Ben, Dhafer Saïdane, and Mehrez Ben Slama. "CSR and Banking Soundness: A Causal Perspective." Business Ethics: A European Review 29, no. 4 (2020): 706-21. https://doi.org/10.1111/beer.12294.

Ahmed, Habib, Z.U. Ahmed, L.M. Algaoud, Simon Archer, R. Baba, Dr Mohd Ma'Sum Billah, King Abdulaziz University, et al. Handbook of Islamic Banking. Edited by M. Kabir Hassan and Mervyn K. Lewis. Cheltenham: Edward Elgar Publishing, 2009: 464. https://doi.org/10.4337/9781847205414.

Akaike, H. "A New Look at the Statistical Model Identification." IEEE Transactions on Automatic Control 19, no. 6 (1974): 716-23. https://doi.org/10.1109/TAC.1974.1100705.

Aliyu, S., M. K. Hassan, R. Mohd Yusof, and N. Naiimi. "Islamic Banking Sustainability: A Review of Literature and Directions for Future Research." Emerging Markets Finance and Trade 53, no. 2 (2017): 440-70. https://doi.org/10.1080/1540496X.2016.1262761.

Aribi, Zakaria, and Simon Gao. "Narrative Disclosure of Corporate Social Responsibility in Islamic Financial Institutions.” Managerial Auditing Journal 27, no. 2 (2011): 199-222. https://doi.org/10.1108/02686901211189862.

Asutay, Mehmet. "Conceptualizing and Locating the Social Failure of Islamic Finance: Aspirations of Islamic Moral Economy vs the Realities of Islamic Finance." Asian and African Area Studies 11, no. 2 (2012): 93-113. https://doi.org/10.14956/asafas.11.93.

Asutay, Mehmet, and Hylmun Izhar. "Estimating the Profitability of Islamic Banking: 
Evidence from Bank Muamalat Indonesia." Review of Islamic Economics 11, no. 2 (2007): 17-29. https://papers.ssrn.com/sol3/papers.cfm?abstract_id=1735651.

Auda, Jasser. Maqasid Al-Shariah as Philosophy of Islamic Law: A Systems Approach. International Institute of Islamic Thought (IIIT), 2008: 1-347.

Bukhari, Syed Asim Ali, Fathyah Hashim, Azlan Bin Amran, and Kalim Hyder. "Green Banking and Islam: Two Sides of the Same Coin." Journal of Islamic Marketing 11, no. 4 (2019): 977-1000. https://doi.org/10.1108/JIMA-09-2018-0154.

Chapra, M. Umer. "The Case against Interest: Is It Compelling?" Thunderbird International Business Review 49, no. 2 (2007): 161-86. https://doi.org/10.1002/tie.20138.

Chen, Roger C. Y., and Chen-Hsun Lee. "The Influence of CSR on Firm Value: An Application of Panel Smooth Transition Regression on Taiwan." Applied Economics 49, no. 34 (2017): 3422-34. https://doi.org/10.1080/00036846.2016.1262516.

Chong, Beng Soon, and Ming-Hua Liu. "Islamic Banking: Interest-Free or Interest-Based?" Pacific-Basin Finance Journal 17, no. 1 (2009): 125-44. https://doi.org/10.1016/j.pacfin.2007.12.003.

Chung, Chune Young, Sangjun Jung, and Jason Young. "Do CSR Activities Increase Firm Value? Evidence from the Korean Market." Sustainability 10, no. 9 (2018): 3164. https://doi.org/10.3390/su10093164.

Dar, Humayon A., and John R. Presley. "Lack of Profit-Loss Sharing in Islamic Banking: Management and Control Imbalances." International Journal of Islamic Financial $\begin{array}{lllll}\text { Services } & 2, & \text { no. } & 2 & \text { (2000): }\end{array}$ https://citeseerx.ist.psu.edu/viewdoc/download?doi=10.1.1.196.5571\&rep=rep1\&type=p df.

El-Gamal, Mahmoud A. Islamic Finance: Law, Economics, and Practice. 1st ed. Cambridge: Cambridge University Press, 2006: 1-221.

Farook, Sayd. "Social Responsibility for Islamic Financial Institutions: Laying Down a Framework." Journal of Islamic Economics, Banking and Finance 4, no. 1 (2008): 6182.

Gangi, Francesco, Mario Mustilli, and Nicola Varrone. "The Impact of Corporate Social Responsibility (CSR) Knowledge on Corporate Financial Performance: Evidence from the European Banking Industry." Journal of Knowledge Management 23, no. 1 (2019): 110-34. https://doi.org/10.1108/JKM-04-2018-0267.

Hafez, Hassan M. "Corporate Social Responsibility and Firm Value: An Empirical Study of an Emerging Economy." Journal of Governance and Regulation 5, no. 4 (2016): 40-53. https://doi.org/10.22495/jgr_v5_i4_p3.

Haniffa, Roszaini, and Mohammad Hudaib. "Exploring the Ethical Identity of Islamic Banks Via Communication in Annual Reports." Journal of Business Ethics 76, no. 1 (2007): 97-116. https://doi.org/10.1007/s10551-006-9272-5.

Hassan, Abul, and Sofyan Syafri Harahap. "Exploring Corporate Social Responsibility Disclosure: The Case of Islamic Banks." International Journal of Islamic and Middle Eastern Finance and Management 3, no. 3 (2010): 203-27. 
https://doi.org/10.1108/17538391011072417.

Herwiyanti, Eliada, Ratu Ayu Sri Wulandari MA, and Ayu Amrina Rosada. "Analysis of Factors Influencing the Islamic Corporate Governance Disclosure Index of Islamic Banks in Asia." International Journal of Humanities and Management Science (IJHMS) 3, no. 4 (2015): 1-6.

Hosen, Muhamad Nadratuzaman, and Fitriyani Lathifah. "Comparison of Halal Certification in Several Countries toward Halal Standard of Indonesia." In Proceedings of the 1st International Conference on Recent Innovations (ICRI 2018), 201-10, 2018. https://doi.org/10.5220/0009921502010210.

Hung, Bill Wan-Sing, and Yan-Leung Cheung. "Interdependence of Asian Emerging Equity Markets." Journal of Business Finance \& Accounting 22, no. 2 (2006): 281-288. https://doi.org/10.1111/j.1468-5957.1995.tb00684.x.

Jan, Amin, and Maran Marimuthu. "Bankruptcy and Sustainability: A Conceptual Review on Islamic Banking Industry." Global Business \& Management Research 7, no. 1 (2015): 109-38. http://www.gbmrjournal.com/pdf/vol. 7 no. 1/V7N1-7-Jan and Marimuthu.pdf.

Jeucken, Marcel. "Sustainable Finance and Banking-Slow Starters Are Gaining Pace." In Sustainable Finance and Banking: The Financial Sector and the Future of the Planet. Oxfordshire: Routledge, 2001: 1-336.

Kamla, Rania. "Critically Appreciating Social Accounting and Reporting in the Arab MiddleEast: A Postcolonial Perspective." Advances in International Accounting 20, no. 8 (2007): 105-77. https://doi.org/10.1016/S0897-3660(07)20005-4.

Kim, Woo Sung, and Sekyung Oh. "Corporate Social Responsibility, Business Groups and Financial Performance: A Study of Listed Indian Firms." Economic Research$\begin{array}{llllll}\text { Ekonomska Istraživanja } 32, & \text { no. } & 1 & \text { (2019): }\end{array}$ https://doi.org/10.1080/1331677X.2019.1637764.

Maali, Bassam, Peter Casson, and Christopher Napier. "Social Reporting by Islamic Banks." Abacus 42, no. 2 (2006): 266-89. https://doi.org/10.1111/j.1467-6281.2006.00200.x.

Malini, Helma. "Determinants of Shariah Banking Performances in Indonesia Through the Perspective of Economic and Social Level." Jurnal Ekonomi Bisnis Dan Kewirausahaan (JEBIK) 9, no. 1 (2020): 47-57. https://doi.org/10.26418/jebik.v9i1.34327.

Masukujjaman, Mohammad, Siwar Chamhuri, Md Reaz Mahmud, and Syed Shah Alam. "Bankers' Perception of Green Banking: Learning from the Experience of Islamic Banks in Bangladesh." Geografia: Malaysian Journal of Society and Space 12, no. 2 (2016): 144-53. http://www.ukm.my/geografia/images/upload/13x.geografia-si-feb16-shahalamedam (1).pdf.

Misbach, Irwan. "Perilaku Bisnis Syariah.” Al-Idarah 5 (2017): 33-44.

Moratis, Lars. "Signalling Responsibility? Applying Signalling Theory to the ISO 26000 Standard for Social Responsibility." Sustainability 10, no. 11 (2018): 4172. https://doi.org/10.3390/su10114172.

Nugroho, Iwan Satriyo, Tombak Gapura Bhagya, and Dian Rosinawati. "Industri Dan Supply 
Chain Halal Dilihat Dari Aspek Keilmuan Teknik Industri." Sainteks: Jurnal Sains Dan Teknik 2, no. 2 (2020): 58-71.

Rahman, Azhar Abdul, Mohd Farid Asraf Md Hashim, and Fathiyyah Abu Bakar. "Corporate Social Reporting: A Preliminary Study of Bank Islam Malaysia Berhad (BIMB)." Issues in Social and Environmental Accounting 4, no. 1 (2010): 18-39. https://doi.org/10.22164/isea.v4i1.45.

Soana, Maria-Gaia. "The Relationship between Corporate Social Performance and Corporate Financial Performance in the Banking Sector." Journal of Business Ethics 104, no. 1 (2011): 133. https://doi.org/10.1007/s10551-011-0894-x.

Soppe, Aloy. "Sustainable Finance as a Connection between Corporate Social Responsibility and Socially Responsible Investing." Indian School of Business WP Indian Management $\begin{array}{lllll}\text { Research Journal 1, no. } 3 \text { (2009): } & 3 & \text { 13-23. }\end{array}$ https://papers.ssrn.com/sol3/papers.cfm?abstract_id=1336182.

Srairi, Samir Abderrazek. "Factors Influencing the Profitability of Conventional and Islamic Commercial Banks in GCC Countries." Review of Islamic Economics 13, no. 1 (2009): 5-30.

Standard and Poor's Rating Services. "Standard and Poor Economic Finance Outlook 2019." New York, 2019.

Wang, Yao, and Qiang Zhi. "The Role of Green Finance in Environmental Protection: Two Aspects of Market Mechanism and Policies.” Energy Procedia 104 (2016): 311-316. https://doi.org/10.1016/j.egypro.2016.12.053.

Wilson, Jonathan A J. "The Halal Phenomenon: An Extension or a New Paradigm?" Social Business 4, no. 3 (2014): 255-71. https://doi.org/10.1362/204440814X14103454934294.

Yousef, Tarik M. "The Murabaha Syndrome in Islamic Finance: Laws, Institutions and Politics." The Politics of Islamic Finance, 2004, 63-80. https://doi.org/10.3366/edinburgh/9780748618361.003.0003.

Zaroni, Akhmad Nur. "Landasan Filosofis Perilaku Konsumen Dalam Perspektif Ekonomi Islam Dan Konvensional." Mazahib 10, no. 1 (2012): 55-68. https://doi.org/https://doi.org/10.21093/mj.v10i1.110. 